\title{
HUBUNGAN KEBIJAKAN PROGRAM INDONESIA SEHAT DENGAN PENDEKATAN KELUARGA TERHADAP ANGKA KEMATIAN BAYI
}

\author{
Zulfanda Manik ${ }^{1}$, Muhammad Badiran ${ }^{2}$, Anto $^{3}$ \\ 1,2,3 IImu Kesehatan Masyarakat, Institut Kesehatan Helvetia \\ Email zulfandamanik15@gmail.com
}

\begin{abstract}
ABSTRAK
Program Indonesia Sehat merupakan salah satu program yang bertujuan untuk meningkatkan kualitas hidup manusia Indonesia, meningkatkan derajat kesehatan dan status gizi masyarakat melalui upaya kesehatan dan pemberdayaan masyarakat yang didukung dengan perlindungan finansial dan pemerataan pelayanan kesehatan. Adapun tujuan penelitian ini yaitu untuk menganalisis hubungan kebijakan Program Indonesia Sehat dengan Pendekatan Keluarga terhadap Angka Kematian Bayi (AKB). Jenis penelitian ini merupakan survei analitik dengan rancangan cross sectional study. Penelitian dilakukan di Kecamatan Karang Baru Kabupaten Aceh Tamiang dengan menggunakan teknik Simple Random Sampling yaitu sebanyak 66 ibu yang memiliki balita. Untuk menganalisis data tersebut digunakan uji Chi Square dan regresi logistik. Berdasarkan hasil penelitian diketahui bahwa Angka Kematian Bayi (AKB) berhubungan dengan keluarga yang mengikuti Keluarga Berencana $(p=0,020)$, ibu melakukan persalinan di fasilitas kesehatan $(p=0,024)$, bayi mendapat imunisasi dasar lengkap $(p=0,006)$, pemanfaatan (ASI) eksklusif $(p=0,038)$, pemantauan pertumbuhan balita $(p=0,000)$. Berdasarkan hasil penelitian, dapat disimpulkan bahwa faktorfaktor yang berhubungan dengan Angka Kematian Bayi (AKB) adalah keluarga yang mengikuti Keluarga Berencana, ibu melakukan persalinan di fasilitas kesehatan, bayi mendapat imunisasi dasar lengkap, pemanfaatan (ASI) eksklusif, pemantauan pertumbuhan balita.
\end{abstract}

Kata kunci: AKB, keluarga berencana, pertumbuhan balita

\begin{abstract}
The Healthy Indonesia Program aims to improve the quality of life of Indonesian people, the health status and nutritional status of the community through health efforts and community empowerment. The objective of this research is to analyze the policy's relationship between the Healthy Indonesia Program and the Family Approach to Infant Mortality Rate (IMR). This type of research is an analytic survey with a cross sectional study design. The study was conducted in Karang Baru Subdistrict, Aceh Tamiang Regency by using Simple Random Sampling technique, namely 66 mothers who had children under five. Chi Square test and logistic regression were used to analyze the data. Based on the results of the study note that the Infant Mortality Rate (IMR) is related to families participating in Family Planning $(p=0.020)$, mothers giving birth in health facilities $(p=0.024)$, infants receive complete basic immunizations $(p=0.006)$, utilization (breast milk) exclusive $(p=0.038)$, monitoring of toddler growth $(p=0,000)$. It can be concluded that the factors related to Infant Mortality Rate (IMR) are families who participate in Family Planning, mothers deliver at health facilities, infants get complete basic immunizations, exclusive use (ASI), monitoring the growth of infants.
\end{abstract}

Keywords: IMR, family planning, toddler growth

\section{PENDAHULUAN}

Pembangunan kesehatan nasional adalah usaha untuk meningkatkan kesadaran, kemauan dan kemampuan hidup sehat bagi setiap orang agar peningkatan derajat kesehatan masyarakat yang setinggi-tingginya dapat terwujud. Pembangunan kesehatan nasional pada periode 2015-2019 adalah Program Indonesia Sehat. ${ }^{1}$

Sasaran Program Indonesia Sehat sesuai dengan sasaran pokok RPJMN 2015-2019, yaitu: (1) meningkatnya status kesehatan dan gizi ibu dan anak, (2) meningkatnya pengendalian penyakit, (3) meningkatnya akses dan mutu pelayanan kesehatan dasar dan rujukan terutama di daerah terpencil, tertinggal dan perbatasan, (4) meningkatnya cakupan pelayanan kesehatan universal melalui Kartu Indonesia Sehat dan kualitas pengelolaan SJSN kesehatan, (5) terpenuhinya kebutuhan tenaga kesehatan, obat dan vaksin, serta (6) meningkatnya responsivitas sistem kesehatan. ${ }^{2}$

Berdasarkan data Kementerian Kesehatan Republik Indonesia tahun (2018), angka Kematian Neonatal (AKN) tetap sama yakni 19/1000 kelahiran, sementara untuk Angka Kematian Paska Neonatal (AKPN) terjadi penurunan dari 15/1000 menjadi 13/1000 kelahiran hidup, dan angka kematian anak balita juga turun dari 44/1000 menjadi 40/1000 kelahiran hidup. Penyebab kematian pada 
kelompok perinatal adalah Intra Uterine Fetal Death (IUFD), yakni sebanyak $29,5 \%$ dan Berat Bayi Lahir Rendah (BBLR) sebanyak $11,2 \%{ }^{3}$

Kebijakan pembangunan kesehatan tahun 2015-2019 difokuskan pada penguatan upaya kesehatan dasar (Primary Health Care) yang berkualitas terutama melalui peningkatan jaminan kesehatan, peningkatan akses dan mutu pelayanan kesehatan dasar dan rujukan yang didukung dengan penguatan sistem kesehatan dan peningkatan pembiayaan kesehatan. ${ }^{1}$

Adapun syarat-syarat kebijakan yaitu : 1) dirancang sesuai dengan kerangka acuan dan teori yang kuat, 2) Disusun korelasi yang jelas antara kebijakan dan implementasinya, 3) Ditetapkan adanya organisasi yang mengkoordinir pelaksanaan kebijakan sehingga proses implementasi dapat berjalan baik, 4) Dilakukan sosialisasi kebijakan yang akan diterapkan sampai organisasi pelaksana tingkat bawah (street level bureaucracy), 5) Dilakukan pemantauan secara terus menerus (monitoring), 6) Diberi bobot yang sama penting antara kebijakan dan implementasinya. Maksudnya, pembuat kebijakan harus menilai sama penting antara kebijakan dan implementasinya. Karena itu, pembuatan kerangka kerjanya dan tindakan lanjutnya mendapatkan perhatian dan fokus yang sama pula, sehingga antara kebijakan dengan implementasinya tidak terjadi kesenjangan yang menyulitkan dalam pelaksanaannya. $^{4}$

Keluarga sebagai fokus dalam pendekatan pelaksanaan program Indonesia Sehat karena menurut Friedman, terdapat Lima fungsi keluarga, yaitu:1) Fungsi afektif (The Affective Function) adalah fungsi keluarga yang utama untuk mengajarkan segala sesuatu untuk mempersiapkan anggota keluarga berhubungan dengan orang lain. 2) Fungsi sosialisasi yaitu proses perkembangan dan perubahan yang dilalui individu yang menghasilkan interaksi sosial dan belajar berperan dalam lingkungan sosialnya. 3) Fungsi reproduksi (The Reproduction Function) adalah fungsi untuk mempertahankan generasi dan menjaga kelangsungan keluarga. 4) Fungsi ekonomi (The Economic Function) yaitu keluarga berfungsi untuk memenuhi kebutuhan keluarga secara ekonomi dan tempat untuk mengembangkan kemampuan individu meningkatkan penghasilan untuk memenuhi kebutuhan keluarga. 5) Fungsi perawatan atau pemeliharaan kesehatan (The Health Care Function) adalah untuk mempertahankan keadaan kesehatan anggota keluarga agar tetap memiliki produktivitas yang tinggi.

Pendekatan keluarga adalah salah satu cara Puskesmas untuk meningkatkan jangkauan sasaran dan mendekatkan/meningkatkan akses pelayanan kesehatan di wilayah kerjanya dengan mendatangi keluarga. Puskesmas tidak hanya menyelenggarakan pelayanan kesehatan di dalam gedung, melainkan juga keluar gedung dengan mengunjungi keluarga di wilayah kerjanya.

Dalam rangka pelaksanaaan Program Indonesia Sehat telah disepakati adanya 12 indikator utama untuk penanda status kesehatan sebuah keluarga. Kedua belas indikator utama tersebut adalah sebagai berikut : 1) Keluarga mengikuti program Keluarga Berencana (KB); 2) Ibu melakukan persalinan di fasilitas kesehatan; 3) Bayi mendapat imunisasi dasar lengkap; 4) Bayi mendapat air susu ibu (ASI) eksklusif; 5) Balita mendapatkan pemantauan pertumbuhan; 6) Penderita tuberkulosis paru mendapatkan pengobatan sesuai standar; 7) Penderita hipertensi melakukan pengobatan secara teratur; 8) Penderita gangguan jiwa mendapatkan pengobatan dan tidak ditelantarkan; 9) Anggota keluarga tidak ada yang merokok; 10) Keluarga sudah menjadi anggota Jaminan Kesehatan Nasional (JKN); 11) Keluarga mempunyai akses sarana air bersih; 12) Keluarga mempunyai akses atau menggunakan jamban sehat. ${ }^{1}$

Berdasarkan survey awal yang dilakukan oleh peneliti di Kecamatan Karang Baru Kabupaten Aceh Tamiang tahun 2019, dengan melihat data sekunder dari Dinas Kesehatan Kabupaten Aceh Tamiang yang masuk per April 2019 yaitu sekitar $40 \%$ dari total jumlah penduduk di Kabupaten Aceh Tamiang, diketahui bahwa adapun Pencapaian Program PIS-PK yaitu sebagai berikut: 1) indikator penggunaan sarana air bersih telah mencapai 96,2 \%; 2) Bayi mendapatkan imunisasi dasar lengkap telah mencapai 92,9 \%; 3) Keluarga memiliki akses/menggunakan jamban keluarga telah mencapai telah mencapai $96,9 \%$; 4) Persalinan Ibu di fasilitas pelayanan kesehatan telah mencapai 95,5\%; 5) Pertumbuhan Balita dipantau telah mencapai 81,3 \%; 6) Bayi mendapatkan ASI Eksklusif telah mencapai 66,4 $\%$; 7) Keluarga sudah menjadi anggota JKN telah mencapai 89,3 \%; 8) Keluarga mengikuti program KB telah mencapai 59,1\%; 9) Anggota keluarga tidak ada yang merokok telah mencapai 37,6 \%; 10) Penderita TB Paru yang berobat sesuai standar telah mencapai 30,2\%; 11) Penderita hipertensi yang berobat teratur 
telah mencapai 23, $2 \%$; 12) Penderita gangguan jiwa berat, diobati dan tidak ditelantarkan telah mencapai $16,7 \%{ }^{5}$

Pada penelitian ini, peneliti hanya akan menganalisis tentang lima (5) indikator yang berkaitan dengan program KIA (Kesehatan lbu dan Anak), yaitu 1) Bayi mendapatkan imunisasi dasar lengkap; 2) Persalinan Ibu di fasilitas pelayanan kesehatan; 3) Pertumbuhan Balita dipantau; 4) Bayi mendapatkan ASI Eksklusif; 5) Keluarga mengikuti program KB yang memengaruhi Angka Kematian Bayi (AKB).

\section{BAHAN DAN METODE}

Penelitian ini menggunakan jenis penelitian kuantitatif dengan rancangan cross sectional study. Lokasi penelitian ini dilakukan di Kecamatan Karang Baru Kabupaten Aceh
Tamiang. Waktu Penelitian berlangsung mulai bulan Oktober sampai dengan November 2019.

Populasi penelitian kuantitatif yaitu seluruh ibu yang memiliki balita di Kecamatan Karang Baru Kabupaten Aceh Tamiang tahun 2019 sebanyak 3298 orang ibu. Teknik yang digunakan adalah Simple Random Random Sampling yaitu sebanyak 66 ibu yang memiliki balita. Data hasil survey dianlaisis dengan menggunakan uji Chi Square dan regresi logistik.

\section{HASIL}

Analisis Data Univariat

Berdasarkan data yang diperoleh dari hasil penelitian dengan 50 responden dapat dilihat dalam tabel distribusi frekuensi sebagai berikut.

Tabel 1. Distribusi Karakteristik Responden Berdasarkan Umur, Pendidikan, dan Pekerjaan di Kecamatan Karang Baru Kabupaten Aceh Tamiang Tahun 2019

\begin{tabular}{cccc}
\hline No. & Umur & $\mathbf{n}$ & $\%$ \\
\hline 1 & $26-35$ Tahun & 39 & 59,09 \\
2 & 36-45 Tahun & 27 & 40,91 \\
\hline & Total & $\mathbf{6 6}$ & $\mathbf{1 0 0}$ \\
\hline No & Pendidikan & $\mathbf{n}$ & $\%$ \\
\hline 1 & SD & 6 & 9,09 \\
2 & SMP & 12 & 18,18 \\
3 & SMA & 28 & 42,43 \\
4 & PT & 20 & 30,30 \\
\hline & Total & $\mathbf{6 6}$ & $\mathbf{1 0 0}$ \\
\hline No & Pekerjaan & $\mathbf{n}$ & $\%$ \\
\hline 1 & Petani & 11 & 16,67 \\
2 & Wiraswasta & 16 & 24,24 \\
3 & IRT & 21 & 31,82 \\
4 & PNS & 18 & 27,27 \\
\hline & Total & $\mathbf{6 6}$ & $\mathbf{1 0 0}$ \\
\hline
\end{tabular}

Berdasarkan tabel 1, diketahui bahwa dari 66 responden, sebagian besar responden berumur 26-35 tahun yaitu sebanyak 39 (59,09\%) responden. Berdasarkan pendidikan diketahui bahwa dari 66 responden, sebagian besar responden berpendidikan SMA yaitu sebanyak 28 $(42,43 \%)$ responden. Berdasarkan pekerjaan diketahui bahwa dari 66 responden, sebagian

Tabel 2. Hubungan Pendekatan Keluarga Pada Keluarga terhadap Angka Kematian Bayi (AKB) di Kecamatan Karang Baru Kabupaten Aceh Tamiang Tahun 2019

\begin{tabular}{|c|c|c|c|c|c|c|c|}
\hline \multirow{3}{*}{$\begin{array}{r}\text { Persalinan diFasilitas } \\
\text { Keluarga Berencana }\end{array}$} & \multicolumn{6}{|c|}{ 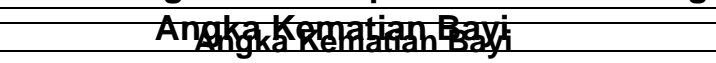 } & \multirow{2}{*}{$\begin{array}{l}\text { P value } \\
\text { P value }\end{array}$} \\
\hline & \multicolumn{2}{|c|}{$\begin{array}{c}\text { Resiko } \\
\text { Meningkat }\end{array}$} & \multicolumn{2}{|c|}{$\begin{array}{c}\text { Resiko } \\
\text { Menurun }\end{array}$} & \multicolumn{2}{|c|}{ Total } & \\
\hline & $\mathrm{n}$ & $\%$ & $\mathrm{n}$ & $\%$ & $\mathrm{n}$ & $\%$ & \\
\hline Tidak & 21 & 31,82 & 14 & 21,21 & 35 & 53,03 & \\
\hline $\mathrm{Ya}$ & 17 & 25,76 & 14 & 21,21 & 31 & 46,97 & 0,020 \\
\hline Total & 38 & 57,58 & 28 & 42,42 & 66 & 100 & \\
\hline
\end{tabular}

besar responden memiliki pekerjaan sebagai IRT yaitu sebanyak 21 (31,82\%) responden.

\section{Analisis Data Bivariat}

Untuk mengetahui hubungan Pendekatan Keluarga pada keluarga terhadap Angka Kematian Bayi (AKB) di Kecamatan Karang Baru Kabupaten Aceh Tamiang Tahun 2019, dapat dilihat pada tabel dibawah ini. 


\begin{tabular}{|c|c|c|c|c|c|c|c|}
\hline & \multicolumn{2}{|c|}{$\begin{array}{c}\text { Resiko } \\
\text { Meningkat }\end{array}$} & \multicolumn{2}{|c|}{$\begin{array}{c}\text { Resiko } \\
\text { Menurun }\end{array}$} & \multicolumn{2}{|c|}{ Total } & \\
\hline & $\mathrm{n}$ & $\%$ & $\mathrm{n}$ & $\%$ & $\mathrm{n}$ & $\%$ & \multirow{4}{*}{0,024} \\
\hline Tidak & 22 & 33,34 & 14 & 21,21 & 36 & 54,54 & \\
\hline Ya & 16 & 24,24 & 14 & 21,21 & 30 & 45,46 & \\
\hline Total & 38 & 57,58 & 28 & 42,42 & 66 & 100 & \\
\hline \multirow{3}{*}{ Imunisasi Dasar } & \multicolumn{6}{|c|}{ Angka Kematian Bayi } & \multirow[b]{2}{*}{ P value } \\
\hline & \multicolumn{2}{|c|}{$\begin{array}{c}\text { Resiko } \\
\text { Meningkat }\end{array}$} & \multicolumn{2}{|c|}{$\begin{array}{c}\text { Resiko } \\
\text { Menurun }\end{array}$} & \multicolumn{2}{|c|}{ Total } & \\
\hline & $\mathrm{n}$ & $\%$ & $\mathrm{n}$ & $\%$ & $\mathrm{n}$ & $\%$ & \multirow{4}{*}{0,006} \\
\hline Tidak & 22 & 33,33 & 13 & 19,20 & 35 & 53,03 & \\
\hline Ya & 16 & 24,24 & 15 & 22,73 & 31 & 46,97 & \\
\hline Total & 38 & 57,58 & 28 & 42,42 & 66 & 100 & \\
\hline \multirow{3}{*}{ Pemanfaatan ASI } & \multicolumn{6}{|c|}{ Angka Kematian Bayi } & \multirow{3}{*}{$\mathrm{P}$ value } \\
\hline & \multicolumn{2}{|c|}{$\begin{array}{c}\text { Resiko } \\
\text { Meningkat }\end{array}$} & \multicolumn{2}{|c|}{$\begin{array}{l}\text { Resiko } \\
\text { Menurun }\end{array}$} & \multicolumn{2}{|c|}{ Total } & \\
\hline & $\mathrm{n}$ & $\%$ & $\mathrm{n}$ & $\%$ & $\mathrm{n}$ & $\%$ & \\
\hline Tidak & 26 & 39,39 & 12 & 18,18 & 38 & 57,58 & \multirow{3}{*}{0,038} \\
\hline $\mathrm{Ya}$ & 12 & 18,19 & 16 & 24,24 & 28 & 42,42 & \\
\hline Total & 38 & 57,58 & 28 & 42,42 & 66 & 100 & \\
\hline \multirow{3}{*}{$\begin{array}{l}\text { Pemantauan Pertumbuhan } \\
\text { Balita }\end{array}$} & \multicolumn{6}{|c|}{ Angka Kematian Bayi } & \multirow{3}{*}{ P value } \\
\hline & \multicolumn{2}{|c|}{$\begin{array}{c}\text { Resiko } \\
\text { Meningkat }\end{array}$} & \multicolumn{2}{|c|}{$\begin{array}{l}\text { Resiko } \\
\text { Menurun }\end{array}$} & \multicolumn{2}{|c|}{ Total } & \\
\hline & $\mathrm{n}$ & $\%$ & $\mathrm{n}$ & $\%$ & $\mathrm{n}$ & $\%$ & \\
\hline Tidak & 33 & 50,00 & 4 & 6,06 & 37 & 56,06 & \multirow{3}{*}{0,000} \\
\hline $\mathrm{Ya}$ & 5 & 7,58 & 24 & 36,36 & 29 & 45,94 & \\
\hline Total & 38 & 57,58 & 28 & 42,42 & 66 & 100 & \\
\hline
\end{tabular}

Berdasarkan tabel 2 diketahui bahwa dari 66 responden yang diteliti, sebagian besar responden tidak mengikuti Keluarga Berencana (KB) yaitu sebanyak $35(53,03 \%)$ responden. Dari 35 (53,03\%) responden tersebut, ada sebanyak $21 \quad(31,82 \%)$ responden tidak mengikuti Keluarga Berencana (KB) dan mengalami peningkatan angka kematian bayi, dan sebanyak $14(21,21 \%)$ responden tidak mengikuti Keluarga Berencana (KB) dan mengalami penurunan angka kematian bayi. Berdasarkan hasil perhitungan uji statistik diperoleh nilai $p$ significancy yaitu $0,020<0,05$, sehingga dapat disimpulkan bahwa ada hubungan pendekatan keluarga pada keluarga yang mengikuti Keluarga Berencana (KB) terhadap Angka Kematian Bayi (AKB) di Kecamatan Karang Baru Kabupaten Aceh Tamiang tahun 2019.

Berdasarkan tabel 2 diketahui bahwa dari 66 responden yang diteliti, sebagian besar responden tidak melakukan persalinan di fasilitas kesehatan yaitu sebanyak $36(54,54 \%)$ responden. Dari $36 \quad(54,54 \%)$ responden tersebut, ada sebanyak 22 (33,34\%) responden tidak melakukan persalinan di fasilitas kesehatan dan mengalami peningkatan angka kematian bayi, dan sebanyak $14(21,21 \%)$ responden tidak melakukan persalinan di fasilitas kesehatan dan mengalami penurunan angka kematian bayi. Berdasarkan hasil perhitungan uji statistik diperoleh nilai $p$ significancy yaitu $0,024<0,05$, sehingga dapat disimpulkan bahwa ada hubungan pendekatan keluarga pada ibu melakukan persalinan di fasilitas kesehatan terhadap Angka Kematian Bayi (AKB) di Kecamatan Karang Baru Kabupaten Aceh Tamiang tahun 2019.

Berdasarkan tabel 2 diketahui bahwa dari 66 responden yang diteliti, sebagian besar responden tidak melakukan pemberian imunisasi dasar pada bayi yaitu sebanyak 35 (53,03\%) responden. Dari 35 (53,03\%) responden tersebut, ada sebanyak $22(33,33 \%)$ responden tidak melakukan pemberian imunisasi dasar pada bayi dan mengalami peningkatan angka kematian bayi, dan sebanyak 13 (19,20\%) responden tidak tidak melakukan pemberian imunisasi dasar pada bayi dan mengalami penurunan angka kematian bayi. Berdasarkan hasil perhitungan uji statistik diperoleh nilai $p$ significancy yaitu $0,006<0,05$, sehingga dapat disimpulkan bahwa ada hubungan pendekatan keluarga pada keluarga yang memiliki bayi 
mendapat imunisasi dasar lengkap pada bayi di Kecamatan Karang Baru Kabupaten Aceh Tamiang tahun 2019.

Berdasarkan tabel 2 diketahui bahwa dari 66 responden yang diteliti, sebagian besar responden tidak memanfatkan ASI yaitu sebanyak 38 (57,58\%) responden. Dari 38 $(57,58 \%)$ responden tersebut, ada sebanyak 26 $(39,39 \%)$ responden tidak memanfatkan ASI dan mengalami peningkatan angka kematian bayi, dan sebanyak $12(18,18 \%)$ responden tidak memanfatkan ASI dan mengalami penurunan angka kematian bayi. Berdasarkan hasil perhitungan uji statistik diperoleh nilai $p$ significancy yaitu $0,038<0,05$, sehingga dapat disimpulkan bahwa ada hubungan pendekatan keluarga pada keluarga yang melakukan pemanfaatan (ASI) eksklusif terhadap Angka Kematian Bayi (AKB) di Kecamatan Karang Baru Kabupaten Aceh Tamiang Tahun 2019.

Berdasarkan tabel 2 diketahui bahwa dari 66 responden yang diteliti, sebagian besar responden tidak melakukan pemantauan pertumbuhan balita yaitu sebanyak 37 (56,06\%) responden. Dari $37 \quad(56,06 \%)$ responden tersebut, ada sebanyak $33(50,00 \%)$ responden tidak melakukan pementauan pertumbuhan balita dan mengalami peningkatan angka kematian bayi, dan sebanyak 4 (6,06\%) responden tidak melakukan pemantauan pertumbuhan balita dan mengalami penurunan angka kematian bayi. Berdasarkan hasil perhitungan uji statistik diperoleh nilai $p$ significancy yaitu $0,000<0,05$, sehingga dapat disimpulkan bahwa ada hubungan pendekatan keluarga pada keluarga yang melakukan pemantauan pertumbuhan balita terhadap Angka Kematian Bayi (AKB) di Kecamatan Karang Baru Kabupaten Aceh Tamiang Tahun 2019.

\section{Analisis Multivariat}

Adapun variable yang paling dominan berhubungan Pendekatan Keluarga pada keluarga terhadap Angka Kematian Bayi (AKB) di Kecamatan Karang Baru Kabupaten Aceh Tamiang Tahun 2019, adalah sebagai berikut:

Tabel 3. Analisis Multivariat Variable yang Paling Dominan Berhubungan

\begin{tabular}{|c|c|c|c|c|}
\hline Variabel & B & $\begin{array}{c}\mathrm{P} \\
\text { value }\end{array}$ & $\begin{array}{c}\text { Exp (B) } \\
\text { OR }\end{array}$ & $\begin{array}{c}95 \% \text { CI for } \\
\text { Exp(B) }\end{array}$ \\
\hline Bayi mendapat imunisasi dasar lengkap & 20,002 & 0,049 & 11,339 & $12,622-43,719$ \\
\hline Pemantauan pertumbuhan balita & 22,334 & 0,036 & 17,921 & $13,721-47,220$ \\
\hline
\end{tabular}

Berdasarkan tabel 3 di atas dapat dilihat bahwa analisis regresi logistik menghasilkan satu variabel yang paling dominan hubungannya dengan Angka Kematian Bayi (AKB) di Kecamatan Karang Baru Kabupaten Aceh Tamiang Tahun 2019 yaitu variabel pemantauan pertumbuhan balita, dengan signifikan 0,036 ( $p$ value $<0,05), \mathrm{OR}=17,921(95 \% \mathrm{Cl}=13,721-$ $47,220)$ artinya responden yang tidak melakukan pemantauan pertumbuhan balita mempunyai peluang 17,921 kali akan terjadi peningkatan angka kematian bayi dibandingkan dengan responden yang melakukan pemantauan pertumbuhan balita. Nilai koefisien B yaitu 22,334 bernilai positif yang artinya semakin banyak responden yang tidak melakukan pemantauan pertumbuhan balita, maka semakin tinggi angka kematian bayi (AKB) di Kecamatan Karang Baru Kabupaten Aceh Tamiang.

\section{PEMBAHASAN}

Pembangunan keluarga adalah upaya mewujudkan keluarga berkualitas yang hidup dalam lingkungan yang sehat (Undang-Undang No. 23 Tahun 2014). Terdapat lima fungsi keluarga, salah satunya adalah fungsi perawatan atau pemeliharaan kesehatan (The Health Care Function) (Friedman, M.R., 1998). Fungsi ini adalah untuk mempertahankan keadaan kesehatan anggota keluarga agar tetap memiliki produktivitas yang tinggi. Fungsi ini dikembangkan menjadi tugas keluarga di bidang kesehatan.Setiap anggota keluarga memiliki peran dan fungsinya masing-masing untuk mempertahankan kondisi kesehatan di dalam keluarga. Kondisi kesehatan yang dipertahankan mencakup pencegahan, perawatan, pemeliharaan, termasuk upaya membangun hubungan timbal balik antara keluarga dengan fasilitas kesehatan. Salah satunya adalah dengan mengikuti KB.

Tujuan Keluarga Berencana (KB) sendiri yaitu untuk peningkatan kesejahteraan ibu dimana indikator utamanya adalah persalinan oleh tenaga kesehatan yang dihubungkan dengan Angka Kematian Ibu (AKI). Oleh karena itu peningkatan pelayanan KB di Kecamatan Karang Baru Kabupaten Aceh Tamiang Tahun 2019 tidak semata-mata untuk pengendalian 
penduduk namun akan berkontribusi dalam meningkatkan kesehatan ibu dan bayi.

Berdasarkan hasil perhitungan uji statistik diperoleh nilai $p$ significancy yaitu $0,020<0,05$, sehingga dapat disimpulkan bahwa ada hubungan pendekatan keluarga pada keluarga yang mengikuti Keluarga Berencana (KB) terhadap Angka Kematian Bayi (AKB) di Kecamatan Karang Baru Kabupaten Aceh Tamiang tahun 2019.

Berdasarkan asumsi peneliti, pelayanan program Keluarga Berencana (KB) juga ditujukan untuk mendukung pencapaian target Millenium Development Goal (MDGs) terutama pont $5 \mathrm{~b}$ mengenai Angka Kematian lbu (AKI) melalui peningkatan kualitas dan cakupan sasaran pelayanan keluarga.

Berdasarkan hasil penelitian diketahui bahwa dari 66 responden yang diteliti, sebagian besar responden tidak melakukan persalinan di fasilitas kesehatan yaitu sebanyak 36 (54,54\%) responden. Dari $36 \quad(54,54 \%)$ responden tersebut, ada sebanyak $22(33,34 \%)$ responden tidak melakukan persalinan di fasilitas kesehatan dan mengalami peningkatan angka kematian bayi, dan sebanyak $14(21,21 \%)$ responden tidak melakukan persalinan di fasilitas kesehatan dan mengalami penurunan angka kematian bayi.

Dari jawaban di atas diketahui pemeriksaan kehamilan pada bidan telah menjadi rutinitas sebagaimana periksa pada dukun, atau dengan kata lain mereka telah memanfaatkan layanan persalinan oleh bidan. Hal ini dilakukan karena adanya kemudahan dari segi jarak dan biaya, juga manfaat yang tidak didapat dari dukun. Namun tidak demikian pada saat persalinan sebagian besar ibu lebih memilih memanggil dukun, dan bidan dipanggil jika terjadi penyulit dalam persalinan.

Hal ini karena karena tempat tinggal dukun lebih dekat dan biayanya terjangkau. Selain itu ibu mempunyai pengalaman persalinan pada dukun yang lebih banyak dan hasilnya juga baik. Senada dengan hal di atas, hasil penelitian Eryando di Tangerang tahun 2007 diketahui bahwa salah satu alasan ibu menggunakan jasa Paraji / dukun untuk periksa kehamilan dan persalinan adalah karena dukun memiliki kemampuan untuk urut yang tidak dimiliki oleh bidan.

Berdasarkan hasil perhitungan uji statistik diperoleh nilai $p$ significancy yaitu $0,024<0,05$, sehingga dapat disimpulkan bahwa ada hubungan pendekatan keluarga pada ibu melakukan persalinan di fasilitas kesehatan terhadap Angka Kematian Bayi (AKB) di
Kecamatan Karang Baru Kabupaten Aceh Tamiang tahun 2019.

Dari hasil wawancara ditemukan bahwa dari segi makanan tidak ada pantangan khusus pada ibu hamil, kalaupun ada tidak wajib dilakukan. Untuk hal-hal yang mempengaruhi lancar tidaknya persalinan hampir seluruh informan mengatakan itu tergantung perbuatan orang tua. Lebih lanjut dikatakan yang terpenting bukan memilih penolong persalinan tetapi bagaimana menjaga sikap selama kehamilan, atau dengan kata lain, lancar tidaknya proses persalinan bukan ditentukan oleh penolong tetapi oleh perbuatan orang tua. Sehingga bila terjadi kesulitan dalam persalinan, suami istri harus saling memaafkan. Dengan saling memaafkan tersebut diharapkan proses persalinan berjalan lancar.

Kebiasaan lain yang diungkapkan oleh masyarakat bahwa seorang bayi baru lahir tidak boleh keluar rumah sebelum mencari hari -hari baik, dan biasanya dilakukan pada usia 3 bulan ke atas. Dari hasil penulusuran di lapangan ditemukan masih banyak bayi dan balita yang tidak mendapatkan imunisasi pada umur kurang dari 3 bulan. Dengan kondisi ini tentu perlu ada tindak lanjut dari pemerintah khususnya di wilayah Sandang Pangan yang masih kental dalam menjaga adat dan tradisi. Walaupun terasa sulit karena menyangkut tradisi dan kepercayaan masyarakat tetapi perlu untuk dicarikan solusi, dan ini tentu tidak hanya bisa dilakukan oleh bidan dan kepala puskesmas, selayaknya Dinas Kesehatan dan Pemkab harus menindak lanjuti permasalahan ini.

Dari hasil wawancara diketahui bahwa posyandu yang berada di tiap desa adalah tempat layanan kesehatan yang paling sering dikunjungi ibu hamil dalam rangka memeriksakan kehamilan. Hal ini juga didukung kemudahan dari sisi jarak dan biaya, dimana untuk periksa hamil tidak dipungut biaya (gratis). Selain itu seluruh informan menilai bahwa fasilitas layanan kesehatan berada dekat tempat tinggal mereka sehingga mudah dijangkau, walaupun ada diantara mereka yang belum pernah menggunakannya, misalnya pasangan bulin keluarga dari desa Sandang Pangan, alasannya karena tidak punya biaya dan merasa jarang sakit, kalaupun sakit mereka hanya mengobati menggunakan air doa dari dukun atau yang dibuat sendiri oleh suami. Namun demikian saat bersalin, sebagian besar informan mengatakan bidan tidak berada di tempat sehingga mereka beralih ke dukun, dimana biaya bersalin pada dukun dirasakan lebih 
murah dan terjangkau.

Mengenai praktek pemanfaatan layanan Persalinan, menurut para tokoh ini , sebagian besar ibu hamil memang memeriksakan diri pada dukun dan juga rutin ke Posyandu. Namun saat melahirkan pihak yang dihubungi adalah dukun karena dukun tinggal dan menetap dikampung, sehingga paling mudah dijangkau. Selain itu masyarakat juga lebih memilih dukun karena ada keragu-raguan dari segi biaya, walaupun mereka telah memiliki kartu Indonesia Sehat. Hal ini dikarenakan selama ini untuk pemeriksaan umum di Puskesmas di Kecamatan Karang Baru Kabupaten Aceh Tamiang tahun 2019 terkadang masyarakat masih harus mengeluarkan biaya tambahan walaupun memiliki kartu Jamkesmas.

Hasil wawancara diketahui masyarakat di Kecamatan Karang Baru Kabupaten Aceh Tamiang tahun 2019 menginginkan dukun sebagai penolong persalinan dengan berbagai alasan yang melatar belakangi seperti kedekatan pribadi dan juga hal obyektif seperti kemudahan untuk dijangkau. Pada sisi lain bidan umumnya belum dikenal karena tidak tinggal dan menetap di desa dan juga bukan penduduk asli . Hasil ini juga sesuai dengan pendapat bidan dan kepala puskesmas yang mengatakan bahwa masyarakat di Kecamatan Karang Baru Kabupaten Aceh Tamiang lebih memilih dukun sebagai penolong persalinan.

Bidan harus tinggal dan menetap didesa agar terjalin komunikasi dan terbina keakraban dengan warga binaannya. Memberikan penyuluhan yang intensif tentang persalinan yang bersih dan aman, dapat dirangkaikan dengan kegiatan arisan desa dan posyandu yang dilaksanakan tiap bulan. Bidan harus meningkatkan pelayanan kehamilan dengan mengunjungi ibu -ibu hamil yang tidak rutin periksa hamil. Selain itu dukun juga perlu diberi pembinaan dan pelatihan tentang cara pemeriksaan pada ibu hamil yang aman. Bidan harus mau memberikan pelayanan persalinan dengan mendatangi rumah ibu bersalin dan juga mengijinkan suami dan keluarga untuk mendampingi ibu selama proses persalinan.

Bidan harus lebih intensif mengadakan pendekatan dengan masyarakat, agar mereka menjadi terbiasa dengan keberadaan dan pelayanan yang diberikan bidan. Dalam memberikan layanan persalinan bidan dapat melibatkan dukun untuk memberi air doa -doa atau tidak melarang ibu untuk mengkonsumsi air doa -doa dari dukun. hal ini untuk memberikan ketenangan pada ibu. Peningkatan pengetahuan tidak hanya dilakukan pada ibu tetapi juga pada suami dan keluarga ibu bersalin. Peningkatan pengetahuan tentang hal -hal yang mempengaruhi kesehatan ibu hamil dan janin yang dikandungnya. Bidan harus menyediakan waktu lebih banyak untuk mengunjungi yang bekerja di kebun. Untuk itu perlu dukungan pemda untuk menyediakan insentif tambahan.

Berdasarkan hasil penelitian diketahui bahwa dari 66 responden yang diteliti, sebagian besar responden tidak melakukan pemberian imunisasi dasar pada bayi yaitu sebanyak 35 $(53,03 \%)$ responden. Dari $35 \quad(53,03 \%)$ responden tersebut, ada sebanyak 22 (33,33\%) responden tidak melakukan pemberian imunisasi dasar pada bayi dan mengalami peningkatan angka kematian bayi, dan sebanyak 13 $(19,20 \%)$ responden tidak melakukan pemberian imunisasi dasar pada bayi dan mengalami penurunan angka kematian bayi.

Kecenderungan ketidakpatuhan, orang tua dalam pemberian imunisasi yang ada di lokasi penelitian disebabkan oleh beberapa alasan antara lain: adanya perasaan khawatir atau takut pada orang tua apabila anaknya diimunisasi akan terkena penyakit. Bagi orang tua yang menolak imunisasi, pihak puskesmas bersama kader posyandu akan mengadakan kunjungan rumah untuk menjelaskan pentingnya imunisasi dasar yang diberikan pada bayi, memberikan pendidikan kesehatan tentang manfaat jangka panjang yang dapat dirasakan apabila melengkapi imunisasi.

Memotivasi orang tua yang menolak imunisasi untuk mau melengkapi imunisasi dasar pada bayinya dan menjelaskan cara untuk menanggulangi efek samping imunisasi dasar seperti demam dengan memberikan obat penurun demam. Pendekatan seperti itu memang perlu dilakukan guna mencoba mengubah persepsi orang tua terkait imunisasi dasar itu sendiri. Peran serta media serta orang sekitar ternyata juga mempengaruhi pandangan atau persepsi orang tua tentang imunisasi dasar. Banyak diantaranya tidak melakukan imunisasi karena mendengar berita tentang vaksin dengan kandungan yang tidak aman dan pengalaman tetangga tentang tidak ada bedanya bayi yang diimunisasi dengan yang tidak serta tentang buruknya efek samping dari imunisasi.

Air Susu Ibu (ASI) merupakan makanan berbentuk cairan putih (susu) yang terbuat secara alamiah yang dihasilkan oleh kelenjar payudara ibu melalui proses menyusui dan termasuk makanan paling tepat, paling berkualitas, dan paling istimewa untuk si buah 
hati. ASI merupakan makanan yang diciptakan oleh Allah SWT kepada kaum perempuan sebagai makanan bernutrisi tinggi dan paling mudah dicerna oleh bayi yang sistem pencernaannya masih rentan.

Rendahnya pemberian air susu ibu (ASI) merupakan ancaman bagi tumbuh kembang anak. Seperti diketahui, bayi yang tidak diberi ASI, setidaknya hingga usia 6 bulan, lebih rentan mengalami kekurangan nutrisi. ASI yang diberikan secara eksklusif (ASI saja) siang dan malam akan membantu suhu tubuhnya tetap terjaga bahkan dalam cuaca panas sekalipun. ASI memberi semua energi dan gizi (nutrisi) yang dibutuhkan selama 6 bulan pertama hidupnya.

Hasil pengamatan peneliti selama membagikan kuesioner di Kecamatan Karang Baru Kabupaten Aceh Tamiang Tahun 2019 menunjukkan bahwa masyarakat di Kecamatan Karang Baru Kabupaten Aceh Tamiang Tahun 2019 tidak semua mengetahui bahwa ASI merupakan sumber gizi yang sangat ideal dengan komposisi yang seimbang dan disesuaikan dengan kebutuhan pertumbuhan bayi, tidak semua mengetahui bahwa ASI sebagai makanan tunggal akan cukup memenuhi kebutuhan tumbuh bayi normal sampai usia 6 bulan, tidak semua mengetahui bahwa ASI adalah zat kekebalan yang terdapat dalam ASI akan melindungi bayi dari diare dan nutrisi yang paling tepat untuk bayi usia 0-6 bulan adalah ASI, tidak semua mengetahui bahwa ASI sangat baik untuk pertumbuhan otak bayi dan meningkatkan kekebalan tubuh bayi. tidak semua mengetahui bahwa manfaat pemberian ASI pada ibu adalah sebagai metode alat kontrasepsi alamiah, dan mengurangi kemungkinan terjadinya kanker payudara dan Rahim Pemeriksaan kehamilan, perawatan payudara dan senam hamil rutin sangat membantu ibu menuju keberhasilan menyusui.

Berdasarkan asumsi peneliti, tingkat pengetahuan yang tinggi ikut menentukan mudah tidaknya ibu untuk memahami dan menyerap informasi tentang ASI eksklusif. Semakin tinggi tingkat pengetahuan ibu, maka makin tinggi pula ibu dalam menyerap informasi tentang ASI eksklusif. Perilaku yang didasari dengan pengetahuan yang baik akan lebih awet daripada perilaku yang tidak didasari oleh pengetahuan. Hubungan tingkat pengetahuan tentang manajemen laktasi dengan perilaku pemberian ASI dipengaruhi oleh pendidikan ibu, pengalaman menyusui sebelumnya dan keterpaparan dengan sumber informasi seperti media massa, petugas kesehatan, dan kontak dengan kelompok ibu yang sudah berhasil menyusui.

\section{KESIMPULAN DAN SARAN}

Berdasarkan hasil penelitian, dapat disimpulkan bahwa faktor-faktor yang berhubungan dengan Angka Kematian Bayi (AKB) adalah keluarga yang mengikuti Keluarga Berencana, ibu melakukan persalinan di fasilitas kesehatan, bayi mendapat imunisasi dasar lengkap, pemanfaatan (ASI) eksklusif, pemantauan pertumbuhan balita.

Sehingga adapun saran dalam penelitian ini diharapkan agar dapat menjadi bahan dan masukan dalam pengambilan kebijakan program Indonesia Sehat dengan Pendekatan Keluarga bahwa kesehatan merupakan hak masyarakat.

\section{REFERENSI}

1. Sekretariat Jenderal Kementerian Kesehatan Republik Indonesia. Pedoman Umum Program Indonesia Sehat Dengan Pendekatan Keluarga. Jakarta Kementeri Kesehatan Republik Indonesia. 2016.

2. Kementerian Kesehatan Republik Indonesia. Rencana Strategis Kementerian Kesehatan 2015-2019. Jakarta Kementeri Kesehatan.2015.

3. RI BLKK. Angka Kematian Ibu Indonesia 2015 telah Disepakati. 2018. 2018.

4. Laelasari E, Anwar A, Soerachman R. Evaluasi Kesiapan Pelaksanaan Program Indonesia Sehat Dengan Pendekatan Keluarga. Jurnal Ekologi Kesehatan. 2017;16(2):57-72.

5. Negara KS. Analisis Implementasi Kebijakan Penggunaan Antibiotika Rasional Untuk Mencegah Resistensi Antibiotika dii RSUP Sanglah Denpasar: Studi Kasus Infeksi Methicillin Resistant Staphylococcus Aureus. Jurnal Administrasi Rumah Sakit Indonesia. 2016;1(1). 